\title{
Penguatan Diplomasi Ekonomi Indonesia Mendesain Clustering Tujuan Pasar Ekspor Indonesia: Pasar Tradisional vs Pasar Non-Tradisional
}

\author{
Sulthon Sjahril Sabaruddin ${ }^{1}$ \\ Kedutaan Besar Republik Indonesia di Sana'a \\ Kementerian Luar Negeri Republik Indonesia \\ Email: ssabaruddin@yahoo.com
}

\begin{abstract}
Abstrak
Studi ini dimaksudkan untuk mengklasifikasi tujuan pasar ekspor Indonesia dengan metode kuantitatif analisis statistik deskriptif selama periode 1962-2015 sehingga dapat menghasilkan sebuah clustering tujuan pasar ekspor Indonesia secara konkrit. Clustering tujuan pasar ekspor Indonesia dibagi menjadi dua macam: pasar tradisional dan pasar non-tradisional (pasar ekspor sudah berkembang dan untapped markets). Hasil analisis menyimpulkan bahwa negara-negara yang masuk dalam kategori pasar tradisional bagi Indonesia sebanyak 12 (dua belas) negara yaitu: Australia, Jerman, Italia, Jepang, Korea Selatan, Belanda, Malaysia, Filipina, Singapura, Inggris Raya, Amerika Serikat, dan Tiongkok (termasuk Hong Kong). Sedangkan, pada kategori pasar non-tradisional, untuk klasifikasi negara-negara ekspor sudah berkembang ditemukan terdapat sebanyak 9 (sembilan) negara yaitu Belgia, Perancis, India, Arab Saudi, Uni Sovyet (dan Federasi Rusia), Spanyol, Thailand, Trinidad and Tobago, dan Vietnam. Sedangkan untuk kategori pasar yang belum digarap (untapped market) adalah seluruh negara dan entitas ekonomi selain diatas (sebanyak 219 negara dan entitas ekonomi). Secara keseluruhan, hasil studi clustering tujuan pasar ekspor Indonesia ini dapat dikatakan cukup selaras dengan banyak pernyataan yang sebagaimana disampaikan oleh pejabat Pemerintahan RI.
\end{abstract}

Kata Kunci: diplomasi ekonomi indonesia, perdagangan, ekspor indonesia, pasar tradisional, pasar non-tradisional, pasar ekspor sudah berkembang, untapped markets, analisis statistik deskriptif

\begin{abstract}
This study attempts to classify the Indonesian export market destination using the quantitative methods of descriptive statistical analysis over the period 1962-2015 so as to generate a concrete clustering of the Indonesian export market destination. The clustering of the Indonesian export market destination is divided into two types: traditional and non-traditional markets (developed export markets and untapped markets). The results of the analysis concluded that the countries that fall into the category of traditional markets for Indonesia are as many as twelve (12) countries, namely: Australia, Germany, Italy, Japan, South Korea, the Netherlands, Malaysia, Philippines, Singapore, United Kingdom, United States, and China (including Hong Kong). Whereas, within the category of non-traditional markets, for the classification of developed export markets it is found there are nine (9) countries, namely Belgium, France, India, Saudi Arabia, the Soviet Union (and the Russian Federation), Spain, Thailand, Trinidad and Tobago, and Vietnam. As for the untapped market category are all countries and economic entities other than previously mentioned (there are 219 countries and economic entities). In overall, the study results of the Indonesian export market destination clustering is quite in tune with the many statements presented by the Indonesian Government officials.
\end{abstract}

Keywords: indonesian economic diplomacy, trade, indonesian export, traditional market, non-traditional market, developed market, untapped market, descriptive statistics analysis

\footnotetext{
${ }^{1}$ Tulisan ini merupakan pendapat pribadi penulis dan bukan cerminan sikap instansi dimana penulis bekerja. Studi ini sebelumnya telah disampaikan ke Kementerian Luar Negeri RI untuk memperoleh masukan guna memperkaya isi dan asas manfaat dari makalah ini. Penulis dapat dihubungi pada email: sulthon.sjahril@kemlu.go.id.
} 


\section{LATAR BELAKANG}

Belakangan ini diplomasi ekonomi telah menjadi perhatian penting dalam politik luar negeri Indonesia. Sesuai visi dan misi program era Pemerintahan Joko Widodo (Jokowi) periode 2015-2019, salah satu program prioritas utama dalam kebijakan luar negeri adalah memperkuat kinerja diplomasi ekonomi Indonesia dengan tujuan untuk turut mendorong pertumbuhan ekonomi dan meningkatkan kesejahteraan masyarakat Indonesia (Sjahril, 2016). Di lingkungan Kementerian Luar Negeri (RI) sendiri, diplomasi ekonomi telah mendapatkan perhatian khusus dan masuk sebagai salah satu dari 8 arah kebijakan yang sebagaimana tercantum pada kebijakan dan strategi Renstra Kemlu Tahun 2015-2019. Dalam mempromosikan hubungan ekonomi Indonesia di luar negeri, terdapat berbagai instansi Pemerintah Indonesia yang membuka kantor perwakilan di luar negeri antara lain: Indonesian Trade Promotion Center (Kementerian Perdagangan RI), Indonesia Investment Promotion Centre (Badan Koordinasi Penanaman Modal), Bank Indonesia, dan Visit Indonesia Tourism Officer (Kementerian Pariwisata dan Ekonomi Kreatif).

Salah satu komponen penting dalam diplomasi ekonomi adalah diplomasi perdagangan. Presiden Jokowi menekankan pentingnya untuk meningkatkan kinerja diplomasi perdagangan Indonesia khususnya mendorong ekspor (terutama ekspor nonmigas) keluar negeri. Dalam beberapa kesempatan, Presiden Jokowi menyampaikan bahwa prioritas tugas Duta Besar RI adalah melaksanakan diplomasi ekonomi dan perdagangan khususnya promosi ekonomi untuk menggenjot ekspor (Kamaludin, 2014). Sebagaimana termaktub dalam Rencana Pembangunan Jangka Menengah Nasional 2015-2019 (RPJMN 2015-2019), kinerja ekspor Indonesia merupakan salah satu sasaran dalam diplomasi ekonomi. Dalam RPJMN 2015-2019 dijelaskan target sasaran ekspor nasional adalah pertumbuhan ekspor produk non-migas rata-rata sebesar 11.6 persen per tahun. Upaya meningkatkan ekspor Indonesia sebesar-besarnya untuk meningkatkan devisa negara, mendorong pertumbuhan ekonomi dan demi kemajuan kesejahteraan bangsa dan negara.

Dalam perdagangan luar negeri RI, selama periode 2011-2015, ekspor Indonesia mengalami tren penurunan sebesar -6.59 persen. Pada tahun 2011, nilai ekspor Indonesia sebesar US\$203 milyar dan kini pada tahun 2015 nilai ekspor Indonesia menurun menjadi US\$150.25 milyar. Dalam menjalankan diplomasi perdagangan, Pemerintah Indonesia secara garis besar telah memetakan secara kasar kawasan dan negaranegara mitra dagang Indonesia menjadi dua kelompok: pasar tradisional dan pasar nontradisional (dahulunya sering disebut sebagai pasar alternatif). Secara umum, pasar tradisional merupakan negara mitra dagang Indonesia yang dinilai telah memiliki hubungan kerjasama ekonomi yang kuat dan menjadi tujuan pasar ekspor Indonesia sejak 
lama seperti Amerika Serikat (AS), Jepang, dan negara-negara kawasan Eropa Barat. Sedangkan, pasar non-tradisional merupakan negara-negara yang potensial secara ekonomi dan prospektif sebagai tujuan pasar bagi Indonesia seperti negara-negara di kawasan Amerika Latin, Eropa Tengah dan Timur, Afrika, Asia Selatan dan Tengah dan Pasifik Selatan.

Tabel 1: Nilai Ekspor Indonesia Selama Periode 2011-2015 (Dalam Milyar US\$)

\begin{tabular}{|c|c|c|c|c|}
\hline $\mathbf{2 0 1 1}$ & $\mathbf{2 0 1 2}$ & $\mathbf{2 0 1 3}$ & $\mathbf{2 0 1 4}$ & $\mathbf{2 0 1 5}$ \\
\hline 203.49 & 190.02 & 182.55 & 176.29 & 150.28 \\
\hline
\end{tabular}

Sumber: Kementerian Perdagangan Republik Indonesia (2016)

Dengan merujuk klasifikasi secara kasar tersebut, Pemerintah Indonesia merumuskan dan mengambil langkah kebijakan diplomasi perdagangan, dalam hal ini khususnya untuk meningkatkan ekspor Indonesia di mancanegara serta merumuskan dan menentukan jumlah sumber daya yang dialokasikan (seperti anggaran promosi ekonomi, sumber daya fisik dan sumber daya manusia) di perwakilan Indonesia luar negeri. Menteri Luar Negeri RI dalam pernyataan pers tanggal 29 Oktober 2014 menekankan pentingnya setidaknya 4 pilar diplomasi ekonomi dan yang terkait dengan diplomasi perdagangan adalah upaya melakukan perluasan dan peningkatan akses pasar produk
Indonesia dengan mendorong perubahan mindset para diplomat Indonesia agar lebih aktif melakukan diplomasi ekonomi bahkan terjun langsung di lapangan (blusukan); serta penguatan kapasitas dan sumber daya perwakilan RI di pasar non-tradisional, atau "untapped market".

Berkenaan dengan hal tersebut, maka kecermatan dan ketepatan dalam menentukan klasifikasi pasar tradisional dan pasar nontradisional menjadi sangat penting dalam mendukung diplomasi dan kebijakan perdagangan Indonesia. Lebih lanjut, studi empiris mengenai pemilihan tujuan pasar ekspor Indonesia secara konkrit (pasar tradisional dan pasar non-tradisional) tampaknya masih minim. Berlandaskan latar belakang tersebut, penulis mencoba untuk merumuskan sebuah pemilahan tujuan pasar ekspor Indonesia dengan metode kuantitatif sehingga diharapkan dapat menghasilkan sebuah clustering tujuan pasar ekspor Indonesia secara konkrit, tidak lagi hanya secara kasat mata (kasar) ataupun pertimbangan subjektif yang sebagaimana tampaknya dilakukan oleh banyak pemangku kepentingan sebelumnya khususnya di lingkungan Pemerintah Indonesia.

\section{STUDI PUSTAKA}

Diplomasi ekonomi merupakan salah satu prioritas penting dalam kebijakan luar negeri Presiden Jokowi demi mencapai pertumbuhan ekonomi dan meningkatkan kesejahteraan nasional. Secara umum, 
diplomasi ekonomi dapat diartikan sebagai suatu upaya yang dilakukan oleh suatu negara (perekonomian) untuk mencapai tujuan ekonomi nasional dengan memanfaatkan instrumen dan sumber daya yang ada. Menurut Kishan S. Rana (2004), diplomasi ekonomi didefinisikan sebagai berikut:

"Economic diplomacy is the process through which countries tackle the outside world, to maximize their national gain in all the fields of activity, including trade, investment and other forms of economically beneficial exchanges, where they enjoy comparative advantage; it has bilateral, regional, and multilateral dimensions, each of which is important".

Dari definisi diatas, dapat tergambarkan bahwa perdagangan internasional dan investasi menjadi perhatian utama dalam diplomasi ekonomi. Maka dari itu tidak mengherankan pada dalam RPJMN 20152019, aspek perdagangan internasional (dalam hal ini meningkatkan kinerja ekspor nasional) menjadi prioritas dalam diplomasi ekonomi Indonesia. Terdapat pula istilah commercial diplomacy (diplomasi perdagangan), tetapi menurut Aleksius Jemadu (2015) dijelaskan bahwa prinsip definisi diplomasi perdagangan juga menekankan unsur-unsur esensial yang sama demi meningkatkan pembangunan ekonomi dalam negeri. Sebagaimana telah dijelaskan pada bab sebelumnya, dalam menjalankan diplomasi ekonomi (dalam hal ini, diplomasi perdagangan), Pemerintah Indonesia secara garis besar telah memetakan secara kasar kawasan dan negara-negara mitra dagang Indonesia menjadi dua kelompok: pasar tradisional dan pasar non-tradisional.

Pembahasan dan perdebatan mengenai pasar tradisional dan pasar non-tradisional Indonesia telah banyak dilakukan sebelumnya. Namun demikian, saat ini sebagian besar terkait pembahasan clustering tujuan pasar ekspor Indonesia ini tampaknya lebih kepada sekedar dugaan dan pandangan dari para pemangku kepentingan (khususnya kalangan Pemerintah Indonesia) serta kalau pun dilakukan kajian lebih sekedar analisis perkiraan awal (dugaan) tanpa ditelaah lebih lanjut secara mendalam. Maka, studi secara mendalam mengenai klasifikasi dan pemilahan tujuan pasar ekspor Indonesia tampaknya masih terbatas.

Terdapat banyak pernyataan yang disampaikan oleh pejabat Pemerintahan Indonesia mengenai perbedaan definisi dan pemilahan pasar tujuan ekspor Indonesia. Wakil Menteri Perdagangan RI dalam suatu kesempatan pernah menyampaikan bahwa telah terjadi diversifikasi pasar ekspor Indonesia dari pasar tradisional (negara maju) ke pasar non-tradisional (pasar berkembang) dan pasar-pasar baru (seperti Afrika) (Susanto dan Rini, 2010). Merujuk pernyataan tersebut, maka secara kasar dapat diinterpretasikan bahwa pasar tradisional Indonesia merupakan pasar tujuan ekspor Indonesia di negara-negara maju, sedangkan yang dimaksudkan dengan pasar non-tradisional adalah pasar berkembang. 
Menko Perekonomian RI pernah menyampaikan bahwa selama ini ekspor Indonesia hanya terfokus pada Tiongkok dan Amerika Serikat yang merupakan pasar tradisional pelaku usaha di nusantara, sedangkan pasar non-tradisional seperti kawasan Afrika dan Asia Tengah perlu digarap (Prayoga, 2015). Di lain kesempatan, Kemendag RI menjelaskan negara dan kawasan pasar tradisional Indonesia seperti AS, Tiongkok, Jepang, Singapura, Malaysia, Thailand, Jerman, Prancis, Inggris, Australia, Korea Selatan dan India. Sedangkan untuk kategori pasar non-tradisional antara lain adalah Afrika, Timur Tengah, Asia Tengah, Eropa Timur dan Amerika Latin (Riyadi, 2012). Lebih lanjut, dalam siaran Pers Kemendag RI disampaikan bahwa transaksi kontak dagang dengan negara-negara Eropa Barat seperti Spanyol, Yunani, Italia dan Inggris masuk dalam kategori pasar tradisional (Kementerian Perdagangan RI, 2008).

Di lingkungan Kementerian Luar Negeri, Menlu RI pada salah satu kesempatan pernah menyampaikan bahwa negara-negara dan kawasan yang masuk kategori pasar tradisional Indonesia antara lain adalah ASEAN, Amerika Serikat, dan beberapa negara Eropa Barat. Sedangkan pasar nontradisional Indonesia antara lain: Eropa Tengah dan Timur, Amerika Latin, dan Afrika (Susanto dan Roza, 2015). Berdasarkan rujukan pernyataan yang disampaikan oleh berbagai pejabat kalangan Pemerintah RI, maka dapat terilustrasikan akan terdapatnya kecenderungan kesamaan pandangan mengenai kawasan pasar yang masuk dalam kategori pasar tradisional dan non-tradisional. Namun jika dilihat berdasarkan negaranya, maka disini tampak adanya beberapa ketidaksamaan negara-negara yang masuk dalam kategori pasar tradisional dan non-tradisional Indonesia.

Maka dari itu, alangkah lebih baiknya jika dilakukan studi secara lebih mendalam mengenai clustering tujuan pasar ekspor Indonesia tersebut. Studi mengenai pemilahan pasar tradisional dan non-tradisional Indonesia tampaknya masih beulm banyak dilakukan. Salah satu dari sedikit studi mengenai pemilahan tujuan ekspor Indonesia tersebut adalah kajian yang dilakukan oleh Kementerian Perdagangan RI (2015). Kemendag RI secara resmi tidak merilis kajian tersebut kepada publik, namun dalam salah satu Diskusi Terbatas (DT) yang dilakukan Pusat Pengkajian dan Pengembangan Kebijakan Kawasan Amerika dan Eropa (Pusat P2K2 Amerop) dengan Kementerian Perdagangan RI pernah didiskusikan secara singkat mengenai upaya Kemendag RI dalam memilah tujuan pasar ekspor Indonesia (Pusat P2K2 Amerop, 2015). Kemendag RI (c.q. Pusat Kebijakan Perdagangan Luar Negeri/PKPLN) menjelaskan bahwa di lingkungan PKPLN pernah melakukan uji coba kajian pemilahan tujuan pasar ekspor Indonesia tersebut.

$$
\text { Kemendag RI (c.q. PKPLN) }
$$
mengklasifikasi pasar tujuan ekspor Indonesia menjadi dua yaitu: pasar tradisional dan pasar non-tradisional. Negara-negara yang masuk dalam kategori pasar tradisional adalah negara 
yang secara konsisten masuk dalam 5 besar tujuan ekspor selama lebih dari 40 tahun. Lebih lanjut, untuk negara kategori pasar nontradisional dibagi menjadi dua macam yaitu negara kategori ekspor sudah berkembang dan negara potensial untuk pengembangan ekspor (untapped market). Dengan memanfaatkan metode tersebut, disimpulkan bahwa negaranegara yang masuk kategori pasar tradisional antara lain: Amerika Serikat, Jepang, dan beberapa negara di kawasan Eropa Barat. Setelah dilakukan clustering tersebut, selanjutnya PKPLN melakukan kajian pemilahan negara potensial diikuti dengan sebuah analisis Market Potential Index (MPI).

Hasil MPI tersebut menjadi masukan penentuan apakah diperlukan Atase Perdagangan di negara tujuan ekspor bagi Indonesia.

Di lingkungan PKPLN Kemendag RI, clustering tujuan pasar ekspor Indonesia juga dimanfaatkan sebagai masukan untuk mengambil saran kebijakan dan diplomasi ekonomi Indonesia. PKPLN membagi dua macam strategi diplomasi ekonomi berdasarkan tujuan pasar ekspor Indonesia yaitu:

1. Negara-negara di pasar tradisional. Arah diplomasi ekonomi Indonesia adalah mempertahankan pasar yang telah dibangun sebelumnya.

2. Negara-negara kategori ekspor sudah berkembang dan untapped countries (pasar non-tradisional). Dalam kategori ini, penekanan diplomasi ekonomi Indonesia adalah membuka pasar baru salah satunya dengan membuka akses pasar.

Tabel 2: Clustering Tujuan Pasar Ekspor Indonesia oleh PKPLN Kemendag RI

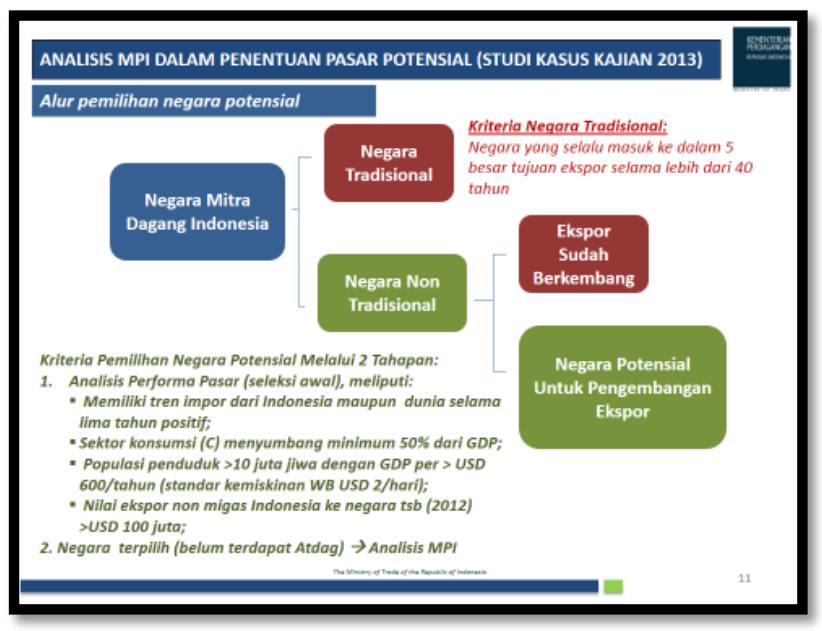

Sumber: Pusat P2K2 Amerop (2015)

\section{METODOLOGI PENELITIAN}

Studi ini mencoba untuk mengklasifikasi tujuan pasar ekspor Indonesia dengan metode kuantitatif sehingga dapat menghasilkan sebuah clustering tujuan pasar ekspor Indonesia secara konkrit, tidak lagi hanya secara kasat mata (kasar) ataupun pertimbangan subyektif sebagaimana tampaknya dilakukan oleh banyak pemangku kepentingan sebelumnya khususnya di lingkungan Pemerintah Indonesia. Studi ini dapat menjadi krusial mengingat clustering tujuan pasar ekspor Indonesia dapat menentukan arah dan strategi diplomasi dan kebijakan perdagangan Pemerintah Indonesia. Lebih lanjut, sebagaimana diungkapkan pada bab sebelumnya, studi empiris mengenai 
pemilihan tujuan pasar ekspor Indonesia secara konkrit (pasar tradisional dan pasar nontradisional) tampaknya masih relatif terbatas.

Dalam menentukan klasifikasi tujuan pasar ekspor Indonesia, penulis merujuk pada pendekatan metode clustering PKPLN sebagai acuan dasar. Sebagaimana metode clustering PKPLN, studi ini akan mengcluster tujuan pasar ekspor Indonesia menjadi dua jenis yakni pasar tradisional dan pasar non-tradisional, dimana dalam pasar non-tradisional sendiri dibagi menjadi dua jenis yaitu negara kategori ekspor sudah berkembang dan negara potensial untuk pengembangan ekspor (untapped market).

Dalam penentuan klasifikasi pasar tradisional, penulis melakukan sedikit redefinisi dari clustering PKPLN yakni negaranegara dan entitas ekonomi yang masuk secara konsisten masuk dalam 15 besar tujuan ekspor Indonesia selama 40 tahun atau lebih. Sedangkan untuk kriteria pasar non-tradisional dibagi menjadi dua yaitu: 1) Kriteria negara ekspor yang sudah berkembang adalah negara yang masuk ke dalam 15 besar negara tujuan ekspor selama 10-39 tahun; 2) Kriteria negara yang belum digarap: selain negara dengan kriteria di atas.

Metode penelitian yang digunakan adalah metode kuantitatif yaitu analisis statistik deskriptif menggunakan tren ranking yang berdasarkan dari definisi clustering tujuan pasar ekspor Indonesia dan kemudian diterjemahkan dalam bentuk tren ranking selama jangka waktu penelitian. Dalam penelitian ini, metode ranking berdasarkan data nilai perdagangan Indonesia dengan negaranegara (serta entitas ekonomi) mitra dagang Indonesia. Pengolahan data dimulai dari pengelompokkan data, perhitungan dan ditabelkan sesuai yang dibutuhkan. Data kuantitatif diolah dengan menggunakan paket program komputer Microsoft Excel yang kemudian hasil output Excel diinterpretasikan.

Dalam penelitian ini digunakan data sekunder, data deret waktu (time series). Data deret waktu meliputi data tahunan nilai perdagangan Indonesia dengan 239 negaranegara dan entitas ekonomi sebagai mitra dagang Indonesia selama periode 1962-2015. Untuk data tahun 1962 dan 1967-2015, penulis memanfaatkan data dari Pemerintah Indonesia (Indonesia sebagai reporter). Sedangkan untuk periode 1963-1966, karena penulis kesulitan memperoleh data nilai perdagangan RI dari Pemerintah Indonesia (Indonesia sebagai reporter), maka penulis memanfaatkan sumber data dari negara (dan entitas ekonomi) mitra dagang Indonesia (negara mitra dagang dan entitas ekonomi Indonesia sebagai reporter). Data nilai ekspor Indonesia tersebut diperoleh dari Kementerian Perdagangan RI dan World Integrated Trade Solution (WITS).

\section{HASIL PEMBAHASAN}

Studi ini mencoba untuk mengcluster tujuan pasar ekspor Indonesia dengan metode kuantitatif analisis statistik deskriptif selama periode 1962-2015. Untuk kategori pasar tradisional Indonesia (lihat kategori kode 1), 
berdasarkan hasil pengolahan data metode kuantitatif tersebut ditemukan terdapat 12 (dua belas) negara yang masuk dalam kategori pasar tradisional bagi Indonesia. Negara-negara yang masuk dalam kategori pasar tradisional Indonesia adalah Australia, Jerman, Italia, Jepang, Korea Selatan, Belanda, Malaysia, Filipina, Singapura, Inggris Raya, Amerika Serikat, dan Tiongkok (termasuk Hong Kong). Dalam studi ini, Tiongkok (Cina Daratan) dan Hong Kong digabung menjadi satu.

Berdasarkan sebaran geografis, maka pasar tradisional bagi Indonesia tersebar di kawasan Asia (6 negara), kawasan Eropa Barat (4 negara), kawasan Amerika (1 negara), dan kawasan Oceania (1 negara). Secara rinci, di kawasan Asia mencakup 3 (tiga) negara anggota ASEAN (Singapura, Malaysia dan Filipina) dan 3 (tiga) negara-negara kawasan Asia Timur (Tiongkok dan Hong Kong, Jepang dan Korea Selatan). Di kawasan Eropa Barat, secara keseluruhan merupakan negara-negara dengan perekonomian besar (dan cukup besar) yakni Inggris Raya, Jerman, Belanda dan Italia. Di kawasan Amerika, hanya diwakili oleh 1 (satu) negara yakni Amerika Serikat yang merupakan negara adidaya. Sedangkan di kawasan Oceania, Australia merupakan satusatunya negara yang masuk kategori pasar tradisional bagi Indonesia di kawasan.

Selama kurun waktu 1962-2015, terdapat 3 (tiga) negara yang selalu masuk dalam kategori 15 besar mitra dagang Indonesia yaitu: Jerman, Jepang dan Amerika Serikat (sebanyak 54 kali). Hal ini menegaskan bahwa ke-tiga negara tersebut memang sudah sejak lama selalu menjadi mitra dagang utama Indonesia, maka tidak mengherankan masuk dalam kategori pasar tradisional Indonesia. Lebih lanjut, terdapat pula 3 (tiga) negara yang hampir selalu masuk dalam kategori 15 besar mitra dagang Indonesia (sebanyak 53 kali) yaitu: Australia, Belanda, dan Tiongkok (termasuk Hong Kong).

Secara garis besar, hasil analisis statistik deskriptif kategori pasar tradisional tampaknya wajar dan konsisten dengan pernyataan dan pandangan yang banyak dikemukakan oleh pejabat Pemerintah Indonesia dari instansi terkait. Menurut pandangan subyektif penulis, mungkin yang agak sedikit di luar perkiraan orang adalah masuknya Italia dalam kategori pasar tradisional Indonesia. Italia merupakan salah satu negara anggota G-20 dengan perekonomian cukup besar, secara geografis cukup jauh (berada di Eropa Selatan) dan secara historis pun tidak memiliki keterikatan hubungan emosional (seperti Suriname, Madagaskar, Belanda, dan Republik Yaman). Bahkan Brasil yang memiliki perekonomian lebih besar dibandingkan Italia saat ini tidak masuk sebagai pasar tradisional Indonesia.

Hasil kajian mengindikasikan bahwa Tiongkok masuk dalam kategori pasar tradisional Indonesia. Namun demikian, jika terdapat pemisahan antara Tiongkok (Cina daratan) dan Hong Kong (sebagai entitas ekonomi), maka Tiongkok (hanya mencakup Cina daratan) tidak termasuk sebagai pasar tradisional Indonesia namun masuk dalam kategori 2, yakni sebagai mitra negara ekspor 
yang sudah berkembang. Sebaliknya, Hong Kong justru dapat masuk dalam kategori pasar tradisional Indonesia.

Tabel 3: Negara-Negara dan Entitas

Ekonomi Kategori Pasar Tradisional

\begin{tabular}{|c|c|c|}
\hline \multicolumn{3}{|c|}{$\begin{array}{c}\text { Negara-Negara (dan Entitas Ekonomi) } \\
\text { Kategori Pasar Tradisional }\end{array}$} \\
\hline Negara & Jumlah & Kode \\
\hline Australia & 53 & 1 \\
\hline $\begin{array}{l}\text { Tiongkok dan Hong } \\
\text { Kong (Total) }\end{array}$ & 53 & 1 \\
\hline Jerman & 54 & 1 \\
\hline Italia & 47 & 1 \\
\hline Jepang & 54 & 1 \\
\hline Korea Selatan & 46 & 1 \\
\hline Malaysia & 42 & 1 \\
\hline Belanda & 53 & 1 \\
\hline Filipina & 44 & 1 \\
\hline Singapura & 51 & 1 \\
\hline Inggris Raya & 47 & 1 \\
\hline Amerika Serikat & 54 & 1 \\
\hline
\end{tabular}

Sumber: Diolah oleh Penulis

Pada kategori pasar non-tradisional, untuk klasifikasi negara-negara ekspor sudah berkembang ditemukan terdapat sebanyak 9 (sembilan) negara yang terdiri dari Belgia, Perancis, India, Arab Saudi, Uni Sovyet (dan
Federasi Rusia), Spanyol, Thailand, Trinidad and Tobago dan Vietnam. Untuk kategori ini, negara mitra dagang Indonesia yang secara konsisten masuk 15 besar selama 25 tahun atau lebih pada periode yang telah ditentukan adalah Thailand (35 kali), Belgia (28 kali), dan Perancis (25 kali).

Berdasarkan distribusi geografis, maka pasar non-tradisional bagi Indonesia kategori negara-negara ekspor sudah berkembang tersebar di kawasan Asia (4 negara), kawasan Eropa Barat (3 negara), kawasan Amerika (1 negara), dan kawasan Eropa Tengah dan Timur (1 negara). Secara rinci, di kawasan Asia mencakup 2 (dua) negara anggota ASEAN (Thailand dan Vietnam), 1 (satu) negara di Asia Selatan (India) dan 1 (satu) negara di Arab Saudi. Di kawasan Eropa Barat, terdapat tiga perwakilan yakni Belgia, Perancis dan Spanyol. Di kawasan Amerika, hanya terdapat 1 (satu) negara yakni Trinidad dan Tobago yang merupakan salah satu negara di kawasan Karibia. Sedangkan di kawasan Eropa Tengah dan Timur, Rusia (Uni Sovyet dan Federasi Rusia) merupakan satu-satunya negara di kawasan yang masuk kategori negara-negara ekspor sudah berkembang bagi Indonesia.

Dari hasil analisis statistik deskriptif, tergambarkan bahwa Uni Sovyet yang merupakan salah satu negara adidaya pada masa perang dingin merupakan mitra dagang utama Indonesia dan menjadi pasar tujuan ekspor Indonesia. Namun setelah runtuhnya Uni Sovyet dan menjadi sebuah negara Federasi Rusia, maka negara ini tidak lagi menjadi negara tujuan ekspor Indonesia yang 
masuk dalam kategori 15 besar. Sehingga jika hanya merujuk data ekspor Indonesia kepada Federasi Rusia saja selama periode 1992-2015, maka Rusia tidak masuk dalam kategori pasar ekspor yang sudah berkembang, namun masuk dalam kode 3 yakni negara potensial untuk pengembangan ekspor (untapped market). Sebaliknya jika dilihat sebagai negara Uni Sovyet saja selama periode 1962-1991, tampak bahwa pada tahun 1960an s/d 1970an, Uni Soviet hampir selalu menjadi pasar tujuan ekspor utama Indonesia, namun agak sedikit menurun setelah memasuki era 1980an hingga 1991. Maka dari itu, gabungan Rusia pada era Uni Sovyet dan Federasi Rusia menjadikan negara ini masuk dalam kategori pasar ekspor yang sudah berkembang bagi Indonesia.

Selanjutnya yang menjadi menarik perhatian adalah Trinidad dan Tobago yang masuk dalam kategori ekspor yang sudah berkembang. Nilai ekspor Indonesia ke Trinidad dan Tobago mencapai masa keemasannya pada periode 1975-1985, dimana sebanyak 10 (sepuluh) kali (periode 19751984) menjadi top 5 besar destinasi ekspor Indonesia. Pada tahun 1985, Trinidad dan Tobago menduduki posisi ke-7 tujuan ekspor Indonesia. Namun pada tahun beikutnya mengalami penurunan yang signifikan. Banyak kalangan yang mungkin tidak menyangka sebuah negara yang tergolong perekonomian kecil di kawasan Karibia yang secara geografis sangat jauh dari Indonesia dapat masuk dalam cluster pasar ekspor yang sudah berkembang. Setelah melakukan penelusuran, selama periode keemasan tersebut, Indonesia mengekspor minyak bumi mentah (crude petroleum, SITC Rev 1 - Kode 33101) ke Trinidad dan Tobago.

Tabel 4: Negara-Negara dan Entitas

Ekonomi Kategori Ekspor yang Sudah Berkembang

\begin{tabular}{|c|c|c|}
\hline \multicolumn{3}{|c|}{$\begin{array}{c}\text { Negara-Negara (dan Entitas Ekonomi) Ekspor } \\
\text { yang Sudah Berkembang }\end{array}$} \\
\hline Negara & Jumlah & Kode \\
\hline Belgia & 28 & 2 \\
\hline Arab Saudi & 12 & 2 \\
\hline Perancis & 25 & 2 \\
\hline India & 18 & 2 \\
\hline Spanyol & 19 & 2 \\
\hline Thailand & 35 & 2 \\
\hline Trinidad and Tobago & 11 & 2 \\
\hline Uni Sovyet dan Federasi \\
Rusia & 13 & 2 \\
\hline Vietnam & 10 & 2 \\
\hline Sumber: Dialah ole Penus & \\
\hline
\end{tabular}

Sumber: Diolah oleh Penulis

Di kawasan ASEAN, terdapat 2 (dua) negara anggota yang masuk dalam kategori pasar ekspor sudah berkembang bagi Indonesia yakni Thailand dan Vietnam. Thailand secara konsisten masuk sebanyak 35 kali sebagai 15 besar tujuan pasar ekspor Indonesia. Sedangkan Vietnam dapat masuk sebanyak 10 kali sebagai 15 besar tujuan pasar ekspor Indonesia. Diduga faktor-faktor seperti 
kedekatan geografis serta hubungan historis dan sosial-budaya, merupakan faktor-faktor berpengaruh yang tidak hanya turut mendorong peningkatan ekspor Indonesia ke Thailand dan Vietnam, namun juga turut meningkatkan nilai perdagangan bilateral. Lebih lanjut, khusus Thailand, sejak tahun 2004, Thailand selalu menempati posisi 10 besar sebagai tujuan pasar ekspor Indonesia. Maka dari itu, penulis berpandangan jika skala waktu kajian ini dilakukan penambahan lima tahun ke depan (misalnya periode 2016-2020), maka diperkirakan Thailand berpotensi masuk dalam kategori pasar tradisional Indonesia.

Sedangkan untuk India, dari sejak dahulu negara ini merupakan salah satu tujuan pasar ekspor Indonesia yang cukup penting dan menjadi semakin penting belakangan ini. Bahkan sejak tahun 1999, India selalu masuk dalam kategori 15 besar tujuan pasar ekspor Indonesia dan pada periode 2013-2014 masuk dalam 5 besar tujuan pasar ekspor Indonesia. Berkembangnya perekonomian India menjadi salah satu perekonomian besar dunia menjadi salah satu faktor utama mengapa belakangan ini India menjadi tujuan pasar ekspor Indonesia. Begitu pula dengan Arab Saudi, yang merupakan salah satu negara anggota G20 dan negara dengan perekonomian terbesar di kawasan Timur Tengah tampaknya menjadi magnet (pull-factor) tujuan pasar ekspor bagi Indonesia.

Terakhir, untuk kriteria negara yang belum digarap (untapped market) adalah negara-negara selain memenuhi kriteria di atas, yakni negara yang masuk ke dalam 15 besar negara tujuan ekspor selama kurang dari 10 tahun. Berdasarkan hasil analisis, maka terdapat 219 negara-negara dan entitas ekonomi yang masuk dalam kategori untapped market selama tahun periode 1962-2015 (lihat tabel 5). Sebagai catatan, penulis hanya memasukkan negara-negara (atau entitas ekonomi) yang minimal satu kali masuk dalam 15 besar tujuan pasar ekspor Indonesia selama periode 1962-2015.

Berdasarkan hasil analisis, beberapa negara kadang dapat dianggap (atau diduga) oleh sebagian kalangan pejabat Pemerintah Indonesia sebagai pasar tradisional Indonesia, namun justru masuk dalam kategori untapped market seperti Kanada, Brasil dan Uni Emirat Arab. Kanada yang merupakan salah satu negara anggota G-8 justru masuk dalam kategori untapped market dan sepanjang sejarah hubungan perdagangan bilateral RIKanada hanya tercatat 2 (dua) kali saja masuk dalam 15 besar tujuan pasar ekspor Indonesia selama periode 1962-2015. Lebih lanjut, negara-negara dengan perekonomian kategori besar dan masuk dalam G-20 seperti Argentina, Brasil, Kanada, Meksiko, Turki dan Afrika Selatan masih dikategorikan sebagai untapped market bagi tujuan pasar ekspor Indonesia. Hal ini menggambarkan bahwa besaran perekonomian di negara-negara mitra dagang Indonesia tidak selalu menjadi faktor yang berpengaruh (atau yang menentukan) bagi tujuan pasar ekspor Indonesia. 
Tabel 5: Negara-Negara dan Entitas

Ekonomi Kategori Negara yang Belum

Digarap

(Untapped Market)

\begin{tabular}{|l|c|c|}
\hline Negara & Kode & Jumlah \\
\hline Uni Emirat Arab & 3 & 6 \\
\hline Denmark & 3 & 5 \\
\hline Selandia Baru & 3 & 5 \\
\hline Pakistan & 3 & 5 \\
\hline Bahamas, The & 3 & 4 \\
\hline Brasil & 3 & 2 \\
\hline Irak & 3 & 2 \\
\hline Swiss & 3 & 2 \\
\hline Yugoslavia, FR & 3 & 2 \\
\hline Serbia/Montenegro) & 3 & 2 \\
\hline Kanada & 3 & 1 \\
\hline Aljazair & 3 & 1 \\
\hline Cekoslovakia & 3 & \\
\hline Liberia & 3 & \\
\hline Polandia & 3 & \\
\hline Swedia & 3 & \\
\hline
\end{tabular}

Sumber: Diolah oleh Penulis

Hal yang menarik justru faktor kedekatan geografis tampaknya lebih nyata berpengaruh terhadap besaran tujuan pasar ekspor Indonesia. Hal ini tergambarkan dengan masuknya beberapa negara-negara ASEAN seperti Singapura, Malaysia dan Filipina (kategori pasar tradisional) serta Thailand dan Vietnam (kategori negara ekspor sudah berkembang). Di kawasan Asia Timur, terdapat Tiongkok (termasuk Hong Kong), Jepang dan Korea Selatan yang masuk dalam kategori pasar tradisional Indonesia. Selain itu, Australia yang merupakan salah satu negara tetangga Indonesia turut masuk dalam kategori pasar tradisional Indonesia. Lebih lanjut, India sebagai salah satu negara emerging countries yang secara geografis terletak tidak terlalu jauh dari Indonesia dapat masuk sebagai negara pasar ekspor sudah berkembang bagi Indonesia.

Dari hasil analisis, penulis menilai setidaknya terdapat 2 (dua) negara yang potensial meningkat statusnya dari kategori untapped market menjadi negara ekspor sudah berkembang dalam waktu beberapa tahun ke depan, yaitu Pakistan dan Uni Emirat Arab. Pakistan merupakan salah satu negara anggota Asia Selatan yang sedang mengalami pertumbuhan ekonomi pesat belakangan ini dan telah menyepakati RI-Pakistan Preferential Trade Agreement (PTA) pada tahun 2012 lalu. Sedangkan Uni Emirat Arab merupakan salah satu negara yang potensial sebagai mitra ekonomi penting bagi Indonesia di kawasan Timur Tengah.

Lebih lanjut, sebagai catatan terdapat pula dua eks-negara berdaulat yaitu: Cekoslovakia dan Yugoslavia. Kedua negara tersebut kini telah pecah yakni Cekoslovakia 
menjadi dua negara berdaulat: Republik Ceko dan Slovakia, sedangkan Yugoslavia dalam proses perpecahan terakhir menjadi dua negara berdaulat: Serbia dan Montenegro. Cekoslovakia dan Yugoslavia pernah masuk dalam 15 besar tujuan pasar ekspor Indonesia pada tahun 1962. Namun setelah kedua negara ini masing-masing pecah, belum ada satu pun negara-negara dari pecahan kedua negara tersebut mampu menembus 15 besar tujuan pasar ekspor Indonesia.

\section{KESIMPULAN DAN SARAN KEBIJAKAN}

Secara keseluruhan, hasil studi clustering tujuan pasar ekspor Indonesia, yaitu pasar tradisional dan pasar non-tradisional dapat dikatakan cukup selaras dengan banyak pernyataan yang sebagaimana disampaikan oleh pejabat Pemerintahan RI. Hasil analisis menyimpulkan bahwa negara-negara yang masuk dalam kategori pasar tradisional bagi Indonesia sebanyak 12 (dua belas) negara yaitu: Australia, Jerman, Italia, Jepang, Korea Selatan, Belanda, Singapura, Malaysia, Filipina, Inggris Raya, Amerika Serikat dan Tiongkok (termasuk Hong Kong).

Pada kategori pasar non-tradisional, untuk klasifikasi negara-negara ekspor sudah berkembang ditemukan terdapat sebanyak 9 (sembilan) negara yang terdiri dari Belgia, Perancis, India, Arab Saudi, Uni Sovyet (dan Federasi Rusia), Spanyol, Thailand, Trinidad, Tobago dan Vietnam. Sedangkan untuk kategori pasar yang belum digarap (untapped market) adalah seluruh negara dan entitas ekonomi selain diatas (sebanyak 219 negara dan entitas ekonomi).

Dalam kategori pasar tradisional, menurut pandangan subyektif penulis, mungkin yang agak sedikit di luar perkiraan orang adalah masuknya Italia dalam kategori ini. Hal ini dikarenakan, walaupun Italia merupakan salah satu negara anggota G-20 dengan perekonomian cukup besar, akan tetapi secara geografis cukup jauh dan secara historis pun tidak memiliki keterikatan hubungan emosional (seperti Suriname, Madagaskar, Belanda dan Republik Yaman). Bahkan Brasil yang memiliki perekonomian lebih besar dibandingkan Italia saat ini tidak masuk sebagai pasar tradisional Indonesia. Sedangkan Tiongkok dapat masuk dalam kategori pasar tradisional Indonesia dengan asumsi digabungkan nilai perdagangan Tiongkok/Cina daratan dan Hong Kong.

Dalam kategori pasar non-tradisional, untuk negara-negara ekspor sudah berkembang yang menjadi salah satu menarik perhatian adalah masuknya Trinidad dana Tobago dalam cluster ini. Negara yang terletak di kawasan Karibia dan sangat jauh dari Indonesia dengan perekonomian yang tergolong kecil mampu menembus cluster pasar ekspor yang sudah berkembang bagi Indonesia. Selain itu, Rusia dapat masuk kategori ini lebih disebabkan penggabungan Rusia sebagai negara Uni Sovyet pada masa perang dingin dan diikuti sebagai Federasi Rusia setelah berakhirnya era Uni Sovyet. 
Sedangkan dalam kategori untapped market, penulis menilai terdapat dua negara yang potensial naik status dari kategori untapped market menjadi negara ekspor sudah berkembang dalam waktu beberapa tahun ke depan, yaitu Pakistan dan Uni Emirat Arab. Selain itu, ditemukan pula dimana negara dengan perekonomian besar seperti Brasil dan Kanada serta beberapa negara anggota G-20 lainnya justru masuk dalam kategori untapped market. Hal ini menggambarkan bahwa besaran perekonomian di negara-negara mitra dagang Indonesia tidak selalu menjadi faktor yang berpengaruh (atau yang menentukan) bagi tujuan pasar ekspor Indonesia. Lebih lanjut, penulis menilai faktor kedekatan geografis tampaknya lebih nyata berpengaruh terhadap besaran dan ranking tujuan pasar ekspor Indonesia. Hal ini tergambarkan dari banyaknya jumlah negara Asia yang turut masuk dalam kategori pasar tradisional dan pasar ekspor sudah berkembang bagi Indonesia.

Studi ini menggunakan metode analisis statistik deskriptif dengan menggunakan tren ranking yang berdasarkan dari definisi clustering tujuan pasar ekspor Indonesia dan kemudian diterjemahkan dalam bentuk tren ranking selama jangka waktu penelitian. Studi ini tentu terdapat banyak simplifikasi, artinya akan terdapat suatu kelebihan maupun kekurangannya. Penulis menilai terdapat ruang yang cukup besar agar penelitian terkait clustering tujuan pasar ekspor Indonesia ini untuk dapat disempurnakan dan dikembangkan lagi ke depannya antara lain dengan menambahkan data ekspor Indonesia sebelum tahun 1962.

Kedua, dengan penyempurnaan dan pengembangan model serta metode analisis kuantitatif sendiri. Sebagaimana telah dijelaskan sebelumnya, kecermatan dan ketepatan dalam menentukan klasifikasi pasar tradisional dan pasar non-tradisional menjadi sangat penting dalam mendukung diplomasi dan kebijakan perdagangan Indonesia. Maka dari itu, penyempurnaan dan pengembangan model serta metode analisis kuantitatif clustering tujuan pasar ekspor Indonesia ini menjadi penting. Tulisan ini diharapkan dapat pula menjadi sebuah rujukan awal clustering tujuan pasar ekspor Indonesia dan masukan dalam mendukung diplomasi dan kebijakan perdagangan Indonesia. Selain itu, studi ini dapat menjadi sebuah embrio atau titik awal untuk mengajak dan mendorong para peneliti, akademisi, mahasiswa, serta praktisi yang tertarik untuk menelaah lebih lanjut clustering tujuan pasar ekspor Indonesia dengan metode yang lebih sophisticated lagi ke depannya baik pendekatan kuantitatif maupun kualitatif (atau keduanya) sehingga dapat menghasilkan sebuah clustering tujuan pasar ekspor Indonesia yang lebih baik lagi ke depan.

\section{DAFTAR PUSTAKA}

Jemadu, A., (2015), "Diplomasi Ekonomi Indonesia: Menuju Solusi yang lebih Komprehensif", Jurnal Hubungan Luar Negeri, Vol. 30, No. 2, Edisi Januari-Juni, Kementerian Luar Negeri RI, Jakarta. 
Kamaludin, A., (2014), "Jokowi akan Tingkatkan Promosi untuk Genjot Ekspor", KataData News and Research, 8 Oktober, Jakarta. Dapat diunduh pada situs:

http://katadata.co.id/berita/2014/10/08/joko wi-akan-galakkan-promosi-untuk-genjotekspor

Kementerian Luar Negeri Republik Indonesia, (2015), "Rencana Strategis 2015-2019 Kementerian Luar Negeri Republik Indonesia”, 6 April, Jakarta. Dapat diunduh pada situs: http://www.kemlu.go.id/Documents/RENS TRA_PK_LKJ/RENSTRA\%20KEMENL U\%202015-

2019\%20FINAL\%20DONE\%20SK\%20M ENLU\%20pdf\%20version.pdf

Kementerian Perdagangan Republik Indonesia, (2016), "Neraca Perdagangan dengan Negara Mitra Dagang", 10 Juli, Jakarta. Dapat diunduh pada situs: http://www.kemendag.go.id/id/economicprofile/indonesia-export-import/balanceof-trade-with-trade-partner-country

Kementerian Perdagangan Republik Indonesia, (2008) "Trade Expo Indonesia 2008: Transaksi dengan Pasar Non-Tradisional Meningkat", 23 Oktober, Jakarta.

Kementerian Perencanaan Pembangunan Nasional Republik Indonesia, (2015), "Rancangan Akhir Rencana Pembangunan Jangka Menengah Nasional 2015-2019”, Buku I Agenda Pembangunan Nasional, Jakarta.

Prayoga, R., (2015), "Indonesia Harus Proaktif Temukan Pasar Baru Tujuan Ekspor", Antara News Lampung Online, 16 Desember, Jakarta. Dapat diunduh pada situs:

http://lampung.antaranews.com/berita/286 931/indonesia-harus-proaktif-temukanpasar-baru-tujuan-ekspor

Pusat Pengkajian dan Pengembangan Kebijakan Kawasan Amerika dan Eropa, (2015), "Analisa Market Potential Index: Studi Kasus Negara-Negara Kawasan Amerika dan Eropa", Diskusi Terbatas dengan Pusat Kebijakan Perdagangan Luar
Negeri Kementerian Perdagangan RI, 23 September, Jakarta.

Kishan, S. R., (2004), "Economic Diplomacy: The Experience of Developing Countries", dalam Nicholas Bayne \& Stephen Woolcock (eds.) The New Economic Diplomacy: Decision-Making and Negotiation in International Economic Relations. Burlington: Ashgate Publishing Company.

Riyadi, S., (2012), "RI Tingkatkan Diversifikasi Pasar Tujuan Ekspor", Finance Roll Online, 7 Februari, Jakarta. Dapat diunduh pada situs: http://financeroll.co.id/news/ri-tingkatkandiversifikasi-pasar-tujuan-ekspor/

Sjahril, S. S., (2016), "Grand Design Diplomasi Ekonomi Indonesia: Sebuah Pendekatan Indeks Diplomasi Ekonomi”, Jurnal Ilmiah Hubungan Internasional, Edisi Maret, Vol. 12, No. 1, hal. 69-90, ISSN - 1693-556X (Versi Cetak). Dapat diunduh pada situs: http://journal.unpar.ac.id/index.php/JurnalI lmiahHubunganInternasiona/article/view/1 $888 / 1800$

Susanto, H., \& Rini, E. S., (2010), "RI Ambisi Jadikan China Pasar Ekspor Terbesar", Viva News Online, 10 Maret, Jakarta. Dapat diunduh pada situs: http://bisnis.news.viva.co.id/news/read/135 390-

ri_ambisi_jadikan_china_pasar_ekspor_ter besar

Susanto, H., \& Roza, A. M., (2015), “Diplomat Harus Menjadi Marketer”, KataData News and Research, 12 Januari, Jakarta. Dapat diunduh pada situs: http://katadata.co.id/opini/2015/01/12/\%E2 $\% 80 \% 9$ Cdiplomat-harus-menjadimarketer\%E2\%80\%9D

World Integrated Trade Solutions (2015), "Trade Database and Trade Indicators", World Bank, 10 Juli. Dapat diunduh pada situs: http://wits.worldbank.org 

